\title{
DEVELOPMENT OF CHARACTER EDUCATION BASED ON LOCAL WISDOM IN INDEGENOUS PEOPLE TENGAHAN SEDANGAGUNG
}

\author{
Dina Anika Marhayani ${ }^{1)}$ \\ 1) STKIP Singkawang, Singkawang, Indonesia \\ E-mail: dinaanika89@gmail.com
}

\begin{abstract}
The character education is built from the values of local wisdom that diverse. The value of local wisdom contains noble values of the ancestor of nation that can be used as capital to establish a nation with good and strong character. The role of local wisdom can be used to develop a character education. This study have reviewed same jurnal literature and article about development of character education based on local wisdom. The first part in the study will introduce the meaning of charater, character education, and local wisdom. The second part will discuss relation of character education and local wisdom, social culture on indigenous peoples Tengahan Sendangagung, the values of the local wisdom on indigenous peoples Tengahan Sendangagung, and the wisdom of the local indigenous people to develop a character education. Finally, the last part of this paper will explain some values of the local wisdom to develop character education.
\end{abstract}

Keywords: character education, local wisdom, indigenous peoples tengahan

\section{INTRODUCTION}

The era of globalization worldwide and easy access to the information obtained, resulting in a cultural exchange that seems indistinguishable the limits of space and time. That is what the Indonesian people perceived at the present time. Cultural exchange absorbed by most Indonesian people without filtering the good and bad according norms and values in the prevailing culture in Indonesia, so the condition of Indonesian national character becomes very worrying. The values of character, especially for the younger generation are very far from the values of the Indonesian culture, particularly on personality. No doubt if the cultural values that are considered noble among the older generation is no longer equal with the younger generation.

The declines of the nation's character values in the governance of life due slacken understanding and implementation of the noble values of wisdom. Human rights become a reason for not obeying to the norms in the Society. This resulted in the Indonesian people seem inclined to leave the nation's culture. However, the incoming foreign culture in Indonesia is not all necessarily bad. There are times when common sense can be accepted, for example: the inclusion of knowledge, education, technology, and so forth, this would broaden the Indonesian nation.

The crisis of character that is increasingly endemic among the younger generation, even the previous generation of the birth concerns. Every day, the ass media is constantly inundated with news stories of crime, murder, increased promiscuity, rampant numbers of violence, adolescent girls, and so on. The case reported in the mass mediated is one of the evidence why national character increasingly worrying. Human beings morality still seems to be a discourse that continues to unfold. Cruelty and savagery become trimmer daily in various media, humanity as the balance of social relations decline and underappreciated, so that people become individuals. One effort that can be done to build the character of the nation through local wisdom.

Viewed from the perspective of anthropology that Indonesia consists of hundreds of tribes that have cultural values and has the advantage of local knowledge (local wisdom) itself, whereas from the perspective of education that education as an effort to preserve culture from one generation to another. Education and culture are complementary and supportive of each other. Education can not be separated by cultural values. How to maintain and preserve their own culture, as well as the most effective transfer by education, for the purpose of education is to preserve and improve the culture. Education is always changing with the development of culture. This then gave birth to the term practice based charater education local wisdom.

Character behavior that appears in everyday life both in attitude and in action [1]. How to develop a character for the younger generation can get through characters education. Character education is behavior that appears in everyday life both in attitude and in action [1]. Talking about characters is very important. Characters distinguish humans from the other beings. People with strong character and both individually and socially are those who have character, morals, and good manners, to develop a strong character for the younger generation through character education.

Character education is a system of value investment of human behavior associated with the God Almighty, ourselves, our fellow human beings, the environment, and nationality embodied in thoughts, attitudes, feelings, words, 
and actions based on religious norms, laws, manners, culture, and customs. Character education in the society one of which is in Tengahan indigenous peoples, who walked in stages and be part of the process and stages of life of its people. So that the values of character that becomes faith society and that must be continually passed on to generations of their children. This is evidenced by the persistence of the values of these characters in the present generation as the generation successor society.

According to Jenkins (2004), the role of local wisdom that critically changing and shaping global culture becomes meaningful and appropriate to the social and cultural life. Local wisdom has a close relationship with the traditional culture of a particular place. Local wisdom contains a view or rule so that more people have a foothold in determining an action such as the behavior of everyday people. Youth who know and adopt the values of local wisdom early, will use it as an analysis in dissecting and separating the value of the element technology. He will be able to determine where things need to be adopted and which need to be leaved. He will always be critical in responding to every phenomenon that it faces. With a clear identity, the youth of this kind will not be easy to follow and join in adopting other cultural values. Thus, he will remain a characteristic local Indonesian human character [2].

\section{METHOD}

Literature review is one of the methods that exist in the research. The theory underlying the problem to be investigated can be found doing a literature study related to the problem studied. Researchers can obtain information about the research in connection with the problem studied. Review of the literature on the take from the study literature review. The study of literature is the study of how data collection with the study riview of literature books, records and reports reated to the problem studied [3]. Pohan in Prastowo (2012), activities preparation of the literature riview has the objective to collect information about scientific studies, in the from of theory-theory, method, or approach that is ever growing and has been documented in the from of boks, journals, manuscripts, notes, recording history, the documents contained in the library. Literature review in this study using the literature related to character, local wisdom, and the literature related with the traditional ceremony of Tunggul Wulung. Review of this role is to reveal the values of local wisdom can be used to develop a character education [4].

\section{DISCUSSION}

\section{A. Character Education and Local Wisdom}

Character education is something that can not from life. Therefore, character education encompasses all aspects of life including in formal institutions and informal. Character education that developed instituted formal, i.e.school. Character education developed at school through cultural values (local wisdom). The material taught in character education not be separated from local wisdom is used as a grip by the service. Local wisdom in he society is one of the material should be contained in character education. Cultural values of other society can be taken as far as not in conflict and can develop the cultural values of their own. This understaning is actually not separated from educaton as a process of inheritance of cultural values of one society to the next generation.

Character education within the indigenous peoples Tengahan, which runs follow the stages and become part of the process of the life of the society. The values of the the character that become the confidence of the society and to be continuously passed on to generaions. As for the value of the character according to the empirical study a curriculum which the value of religious, honest, tolerance, discipline, hard work, creative, independent, democratic, curiosity, the spirit of nationality, the love of the homeland, appreciate the achievements, friendly and communication, love peace, fond of reading, care of the environment, care of social, and have a sense of responsibility.

When viewed from the aspect of education in relation with local wisdom that the value of cultural values into material study of the formation of character. Local wisdom as the cultural values that have become the hallmark of the area can be used as a source in developing the character. Character education comes from local knowledge as the cultural heritage of the sublime will make the children of the nation became the source of the power of civilized man. Local cultute the start of the curremt must always be maintained to strengthen the nation.

\section{B. Socio-Culture Indigenous Tengahan Sendangagung}

Indigenous peoples showed a close relationship in the personal relationship and the social interaction that occurred between humans, raised certain pattern called a uniform or customary way of behaving within a social group [5]. One of the indigenous peoples who have typical in the culture of indigenous peoples Tengahan. Tengahan indigenous peoples are communities in the villages Sendangagung. Sendangagung is entrance area of the districts in Sleman, Yogyakarta Special Regio. Sendagagung is located $21 \mathrm{~km}$ to the west of the city of Yogyakarta. The state of the soil conditions in the region Sendangagung in the from of paddy fileds that are created with a sysem of terracing. Soil conditions Sendangagung very fertile, so it is used for agricultural land, especially rice, wih such conditions people quite fulfilled his need to obtain a good harvest and abundant.

Tengahan public administration system recognizes two systems of government, the customs administration system and village administration system. The second system of government is very different division of labor. The supreme leader of traditional governance structure is held by an indigenous stakeholder. The function of indigenous stakeholders more focused on the policy of the customary law, as well as supervise the implementation of customary law on indigenous peoples Tengahan, including monitoring violations of customary law, both by society. The 
management structure of village government, led by the village head.

Tengahan society is a society that has a distinctive indigenous. The traditional ceremony Tengahan people always focus on "cult" of the figure Ki Ageng Tunggul Wulung is believed as the ancestors. People Tengahan assume that Ki Ageng Tunggul Wulung as ancestors of the Majapahit kingdom. For that, ceremonies are well known in the society Tengahan the ceremony Tunggul Wulung taken from the figure of $\mathrm{Ki}$ Ageng Tunggul Wulung. The traditional ceremony which is famous in the ceremony Tengahan society Wulung stumps. Wulung Tunggul ceremony performed on Friday Pon is believed to be a sacred day by Ki Ageng Tunggul Wulung. In addition, the harvest rendhengan (rainy season) will determine the timing of the ceremony. Tayub traditional dances and drinking alcohol is series of ceremonies.

Nayub comes from the word tayub, consists of two words that Mataya which means dance and guyub which means in harmony together. It is estimated that there is a change of two words into one word, ma-ta-ya and gu-yub be tayub [6], while in-tayub mean invited to dance [7]. Tayub Dance is an art of rituals as a from of gratitude for the fertility of the natural results. Society lives are still dominated by an agrarian culture. This reflects ledhek dancers have an important role in rituals for fertility and safety. Fertility associated with the harvest often sassociated with Dewi Sri or Goddess of Fertility. According to local belief is compulsory dance Tayub ceremony staged in order Ibadan, when dance Tayub is not staged the ceremony will be invalid and is believed will bring disaster pageblug (heavy rain) [8].

Pengrawit also acquired an important role in the implementation of the ceremony of Ki Ageng Tunggul Wulung. Without the presence of gamelan musicians, the ceremony can not run properly. Gamelan musicians in the ceremony of Ki Ageng Tunggul is a society. The Majority of gamelan musicians aged old and over are tasked with beating the gamelan and the sound gending gending sounded in the implementation of the ceremony [8]. Dance Tayub and Pengrawit is a art should be there at the ceremony Tunggul Wulung in the Tunggul Wulung society.

In general, many mystical Javanese art, one of which is dancing Tayub. It is said that the dancers Tayub use mystical ways, such as the use of the implant as a lure to attract viewers. Shades of Mystical of dance Tayub make me a perception of society as folk art. Magical and mystical symbols that exist in this art are characteristic of culture Abangan, the fringes of society religious culture Kejawen. This art is develop in java society [8]. This means that this art can only grow and develop in a limited location i.e. java.

\section{The values of Indigenous Peoples Adat Tengahan}

In Inonesia, each tribe has a unique local wisdom. Local wisdom is along process that contains the values of the good for the life of society. The values of kindness make the local knowledge become a culture that has been strongly attached to the life of the society. The society always keeping the existence of local wisdom. These are the things that happen on the local wisdom of indigenous people Tengahan. Local wisdom of indigenous peoples seves as a reinforcement of tribal identity, as a filter the value that comes from the outside, as a oothold in developing the noble values to internalized in character education.The values in local wisdom Tengahan that can applied to the learners in order to develop character, among other things:

\section{1) Religius}

The value of religion can be defined as attitudes and behaviors that are obedient in carrying out the teachings of the religion, tolerant implementation of worship of other religions, and live in harmony with adherents of other religions. The majority society Tengahan are farmers who are still obedient to the beliefs espoused, namely trust in the existence of ancestral spritis and trust the supernatural powers of Dewi Sri.

2) Environment Care

Enviromment care is an attitude in developing concern for the environment. The manjority society Tengahan are farmers who still believe in the exixtance of ancestral spirits who maintain nature and well being for society. The citizens of the community regularly holds ceremonial Tunggul Wulung as an expression of gratitude. Ritual Tayub Tunggul Wulung has a meaning consists of two dimensions, both vertically and horizontally. Ritual Tayub Tunggul Wulung has a meaning consists of two dimensions, both vertically and horizontally. The vertical dimension is the worship to the ancestors as an act of gratitude has been given natural resources as the harmony of nature, man, and God. The horizontal dimension is an attempt to preserve the environment and to astablish ineractions between individuals in society in order to stay awake.

3) Social Care

Social care is the attitude of a person t do good deeds toward others which help others. Social activities are always done with a spirit of mutual assistance and helping each other. Indigenous Tengahan who is always promoting the spirit of mutual cooperation, for example in the indigenous peoples in mutual cooperation to prepare all the needs in the implementation of the ceremony of the Tunggul Wulung. Society and traditional keaders to cooperate with each other regardless of social status. All the society participated together.

\section{4) Tolerance}

Tolerance is an attitude of human respect every activity that other people do. The attitude of tolerance should be developed in order to create harmony. Indigenous people Tengahan have a high tolerance in respect of inter-religious. Indigenous Tengahan muslim majority and another society still adheres to the belief of ancestral spirits. The muslim society participated in the activities of Tunggul Wulung as a form of tolerance to people who still have a belief in the spirits of ancestors. 


\section{5) Responsible}

The responsibility which a man's attitude to feel responsible for all the deeds done. Responsibility is one characteristic of a civilized human. The behavior of the indigenous Tengahan are responsible for the implementation of the ceremony of Tunggul Wulung, such as the participation of the society in the following series of activities, among other: the preparation of the ceremony, the preparation of making offerings, and the ceremony.

All citizens help to prepare ceremony and all the needs as mutual. All the activities and the active role of the Society Tenagahan Sendangagung an response from the public reception to maintain and preserve the stumps ceremony Tunggul Wulung Ki Ageng Tunggul Wulung interpreted as a heritage that brings a positive influence in people's lives. The values contained on the local wisdom is still instilled in their children and grandchildren. The values of those internalized in their behaviour everday in order to from the characters that have the characteristic of in accordance with loka wisdom of the indigenous peoples Tengahan.

\section{The Wisdom of The Local Indigenous Peoples Tengahan to Develop a Character Education}

Local wisdom of the indigenous peoples Tengahan can build character. The values of local wisdom into attitudes and beliefs internalized citizens and preserved continuously both in informal educations such as family and community, as well as formal education at school. In the family and community is done through various forms including; local values are taught so they will know familiarized local values in everyday life in order to become behavior, exemplified so that there is an exemplary figure, as well as customary rules are firmly upheld so that people have a strong character.

Character education in school is not limited to knowledge. Character education is important to make sure that these values remain embedded and integrated in thought and action. The values contained in the local wisdom of indigenous peoples Tengahan such as religious, environmental care, social care, tolerance, and responsibility of preserving the tradition can be implemented in learning. Lessons taken from the values of local wisdom that suit the environment and experienced by students. Thus, students will be more motivated to learn, so that learning becomes more meaningful. The development of character education can be through the activities of students in school, for example by organizing extracurricular dance art, such as dance tayub. Extracurricular activities of students in schools is beneficial to increase the love and preserve the local culture. The development of character education need a method of habituation and exemplary in the school. The valu of religious, environmental care, social care, tolerance, and responsibility contained in the local wisdom should be socialized in school. It is necessary the cooperation of all society schools, in particular teachers and principals who serve as an example for students.
At school the values of local wisdom can be developed in a matter of learning. The values local wisdom of indigenous peoples that is the mutual cooperation values, a sense of sincerity, a sense of togetherness, mutual help, and the attitude of preserving tradition, constantly internalized both the formal and informal education to make them have the strong character in their daily lives. The process of character formation which conducted continuously at home, at school and in the community will produce a characteristic behavior. Character education comes from local wisdom as the cultural heritage of the ancestors will make the children of this nation to succeed in the academic and economic fields that can prepare them to be human resources civilized and prosperous future.

\section{CONCLUSIONS}

National character can not be separated from the people who support preserving the cultural wisdom region. Because the character of the nation is a nation that explore the values of local wisdom to serve as a guide so that a nation is not lost in this modern world. A good education is also becoming one of the factors supporting the creation of a national character within the individual communities. Character education based on local wisdom is expected to improve at least a little by little crisis experienced by the character of this nation now. With the character education based on local wisdom is expected to create generations that is rich in character and wisdom of local culture can develop properly.

Indigenous peoples Tengahan are a society that has a characteristic that is different from other indigenous peoples. Local Wisdom of Indigenous Peoples Tengahan as mutual cooperation, a sense of sincerity, a sense of togetherness, mutual help, and the attitude of preserving tradition. Reflections on the behavior they show a form of seriousness attitude which was planted continuously to our ancestry through a long educational process and have proven efficacy even though the times keep changing and external challenges continue to attack. The values contained in the local wisdom of indigenous peples Tengahan implemented the learning and familiarized in school. This paper reviews the outline of the values of local wisdom Tengahan, such as mutual cooperation, a sense of sincerity, a sense of togetherness, mutual help, and attitude preserve the tradition can be used as educational development of good character.

\section{REFERENCES}

[1] S. Muchlas and Hariyanto, Concepts and models of Character Education. Bandung: Remaja Rosdakarya, 2011.

[2] H. Jenkins, Pop Cosmopolitanism: Mapping Cultural Flows in an Age of Media Convergence in the New Millennium (edeteds), Marcelo M. Suárez-Orozco and Desirée Baolian Qin-Hilliard University of California Press Berkeley and Los Angeles, California., 2004.

[3] M. Nazir, Research Method. Jakarta: Ghalia Indonesia, 2005.

[4] A. Prastowo. Qualitative Research Methods in the Perspective of Research Design. Yogyakarta: Ar-Ruzz Media, 2012. 
[5] H. Nurtjahjo and F. Fokky. Legal Standing of Indigenous People Unity litigate in the Constitutional Court. Jakarta: Salemba Humanika, 2010.

[6] B. Suharto, Tayub Performance and Fertility Rites. Yogyakarta: Performing Arts Society, 1999.

[7] Mangunsuwito. Complete Dictionary of the Java language. Bandung: CV Yrama Widya, 2002.
[8] L.Widati, "The Reception of the society to the Tayub Dance in a Ritual Ceremony Clean Village of Ki Ageng Tunggul Wulung in the Hamlet of Tengahan". Skripsi, Unversity State of Yogyakarta, Yogyakarta, Indonesia, Sept.2012. 